\title{
The Clash of Civilizations: a Myth?
}

\section{Ali Muhammad}

Jurusan IImu Hubungan Internasional, Fakultas IImu Sosial dan IImu Politik, Universitas Muhammadiyah Yogyakarta

Ringroad Barat Tamantirto, Kasihan, Bantul 55183

Email:alim@yahoo.com

\begin{abstract}
Abstrak
"The Clash of Civilizations" adalah sebuah metafora kontroversial yang berkembang di politik global pasca perang dingin. Diperkenalkan oleh Samuel Huntington, metafora tersebut menyarankan bahwa politik dunia mengalami konfigurasi ulang yang "fault line" antara budaya menggantikan batasan politik dan ideologi sebagai "flashpoint krisis dan pertumpahan darah". Tujuan dari artikel adalah untuk mengkaji secara kritis proposisi dan asumsi teoretikal yang menguatkan tesis. Hal ini menunjukkan bahwa proposisi tidak berdasar dan asumsi teoretikal dibalik argumen kurang dapat dipercaya. Ini memperdebatkan bahwa "clash of civilizations" merupakan mitos belaka.

Kata Kunci: Peradaban, konflik, Barat, Islam
\end{abstract}

\section{Abstract}

"The clash of civilizations" is a powerful metaphor of the post cold war global politics. Introduced by Samuel Huntington, the metaphor suggested that world politics were being reconfigured with 'fault line' between cultures replacing political and ideological boundaries as 'the flashpoints of crisis and bloodshed'. The purpose of this article is to critically examine the propositions and theoretical assumptions underpinning the thesis. It shows that the propositions are groundless and the theoretical assumptions behind the argument are dubious. It argues that the "clash of civilizations" is a myth.

Keywords: civilizations, conflict, the West, Islam

\section{INTRODUCTION}

The term "the clash of civilizations" was introduced by Professor Samuel Huntington in the context of the post-cold-war global politics. When the communist states in Eastern Europe fell, the Soviet Union collapsed, and the Cold War finally ended, global politics enters a new phase. Political scientists competed to draw metaphors what the world politics will be. The end of history (Fukuyama, 1989) ${ }^{1}$ the coming anarchy (Kaplan, 1994) ${ }^{2}$ the unipolar moment (Krauthammer, 1991) ${ }^{3}$ globalization (Albrow, 1990), ${ }^{4}$ are among others. Huntington rejects those metaphors because they all miss the crucial aspect of what global politics is likely to be and offers a controversial, provocative image of the post-Cold War global politics: the clash of civilizations (Huntington, 1997). The purpose of this article is to challenge Huntington's thesis and to show the danger if we are trapped into his scenario: the clash of civilization is a myth.

\section{ANALYSIS}

\section{THE CLASH OF CIVILIZATIONS}

Huntington's main aim to write the book (The Clash of Civilizations and the Remaking of World Order) is, first, to draw a map of the post-cold war world poli- 
tics, secondly, to warn the West of the rise of a new danger and a threat after its former enemy (communist block) withered away, and thirdly, to offer a policy guide for policymakers in the West of the new environments of global politics. Borrowing his words "...aspire to present a framework, a paradigm, for viewing global politics that will be meaningful to scholars and useful to policymakers" (1996: 13). He is sure that his is the best paradigm to understand post cold war world politics and challenges the critiques by asking rhetorically, "...if not [the clash of] civilizations, what? "Got a better idea?" (Huntington, 1993: 191).

But, what exactly are his arguments? (Chen, 1997) The end of the cold war is a significant phase of world politics. He argues that the most important of grouping of states in the world politics are no longer the three blocs of the cold war era-the First World, the Second World, and the Third World, but new blocs of seven or eight civilizations (Huntington, 1996: 21). The fundamental sources of conflict in the post cold war world politics, he continues to argue, will not be primarily ideological or primarily economic. The great divisions among human kind and the dominating source of conflict will be cultural and the principle conflict of global politics will occur between nations and groups of different civilizations. The clash of civilizations will be a battle line of the future (Huntington, 1996: 29-30).

Let's look further at the main propositions he set forth. First, for the first time in history global politics/ international relations are both multipolar and multicivilizations. The process of modernization outside the West is producing neither a universal civilization nor the westernization. Instead, it produces indigenization: reaffirmation of their own cultures and values. Secondly, the balance of power among civilizations is shifting. The West is declining in its relative influence, but Asian (especially, Confucian) civilizations are expanding their economic, military, and political strength. Islam is exploding demographically with the destabilizing consequences for Muslim countries and their neighbors. Thirdly, a civilizationbased world order is emerging. Societies sharing cultural affinity cooperate with each other; effort to shift society from one civilization to another are unsuccessful; and countries group themselves around the core states of their civilization.

Fourthly, the west's universal pretensions increasingly bring it into conflict with other civilizations, most seriously with Islam and China; at the local line fault line wars largely between Moslem and nonMuslim, generate "kin-country rallying," the threat of broader escalation, and hence effort by core states to halt the wars. Finally, the survival of the west depends on how successful Americans reaffirms its identity as a unique, not universal, and how solidly the West unites against challenges from "the Rest" (Huntington, 1996: 20).

\section{THE GROUNDLESS PROPOSITIONS}

Huntington's propositions are serious fallacies and oversimplification of complexities of world civilizations so that they are of little use for understanding the complexity of post cold war global politics. Lets have a look at each proposition. First, the rise of multipolar and multi-civilization global politics. Huntington argues that modernization and globalization produces neither a universal civilization nor westernization of non-western society. Instead, it produces indigenization: cultural and religious resurgence. So, he is a globalization skeptic. ${ }^{6}$ Bassam Tibi in his book Krieg der Civilizationen confirms this observation (Tibi in Herzog, 1999) ${ }^{7}$ Lets look at Huntington's diagram bellow (Huntington, 1996: 76):

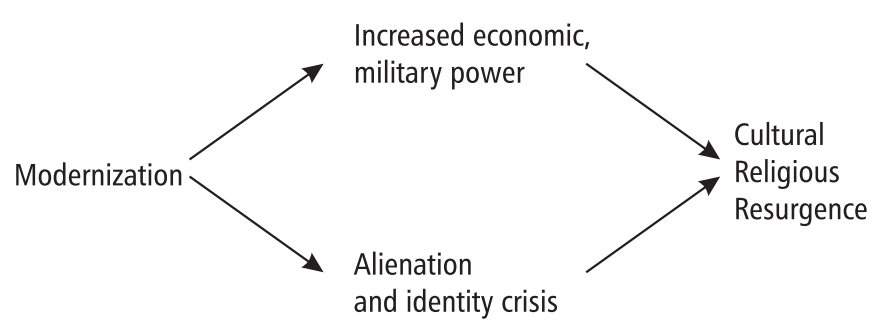

Huntington continues to argue that the difference of cultural identity around the globe promotes new cultural and civilizational blocs, replacing the old blocs of ideologies during the cold war. A civilization is defined as a subjective self-identification of people, 
as well as by such factors as language, history, religion, customs, and institution. It is, therefore, the broadest level of human species. Civilization are long lived, they evolve and adapt (Huntington, 1996: 43). He points out that currently there are seven or eight major "block" of civilizations: Sinic, Japanese, Hindu, Islam, Orthodox, Western, Latin American, and possibly African (Huntington, 1996: 45-48). This fragmentation of the world along civilizational blocs leads to the danger of conflict. Huntington argues, “...the most dangerous cultural conflicts are those along the fault lines between civilizations" (Huntington, 1996, 13). He constructs a clear-cut boundary between the west and orthodox Christianity and Islam from Finland in the north and the former Yugoslavia in the south. Using the realist model of billiard balls, he shows as if there are clear-cut boundaries among eight civilizations.

However, there is a serious problem here. The block-based thinking of civilizations is really unpersuasive. He arbitrary demarcates the seven or eight "civilizations" as if they were monoliths, as if they did not overlap in reality and frequently interpenetrate (Kung in Herzog, 1999: 101). In fact, nearly every civilization that Huntington mentions involved absorption, assimilation, interdependence, and interpenetration one another (Muzzafar, 1994: 11). For instance, through centuries of exchange with the west, Islam laid the foundation for the growth of mathematics, science, medicine, agriculture, and industry in Medieval Europe. Islam in practice contributed to strengthening the foundations of the European Renaissance (Esposito, 1995: 207-8). And today, some of the leading ideas and institutions that have gained currency within the Muslim world are imported from the West. So, each civilization penetrates one another. Relations between Hindu and Islam provide another example. Islam impacted upon the architecture, law, the literature and attire of segment of the Hindu population just as Hinduism also influences Muslim mysticism, food and music Muzaffar, 1994: 11). So, constructing a clear-cut demarcation and block-based thinking of civilizations is not persuasive.

Second, the shift of the balance of power among civilizations. Huntington argues that the west is in its peak, but currently it is declining in relative influence. On the other hand, Asian civilizations are expanding their economic, military, and political strength. Islam is exploding demographically with the destabilizing consequences for Muslim countries and their neighbors. It seem that Huntington's observations is inspired by, firstly, the story of East Asian economic "miracle" (before the 1997 financial crisis) and, secondly, orientalism and the popular discourse in the West of Islamic revivalism since the 1970s.

It seems interesting that he uses also the realist model of "the balance of power" to understand the relations among civilizations. In anarchic world politics ${ }^{8}$, the increase of power of "non-western civilizations" will pose a serious danger and threat to the declining "western civilization." Huntington attempts to prove his arguments-as other realists doby comparing the power and capabilities of each civilization in term of the total territories, populations, economic products, the share of world manufacturing output, share of Gross National Product and the military capabilities. All in all, he wants to show that the west civilization is in decline relative to the "Confucian" and "Islamic" civilization (Huntington, 1996: 83-88).

However, the proposition has serious methodological fallacies so that his arguments could not work. If he wants to make valid comparison among civilizations he must ensure that there is clear unity in each civilization. In fact, he cannot. There is no unity, for instance, within Cinic or Islamic civilization. The split and division within each civilization is more apparent than between civilization (Gershman, 1997: 165-170, Kung, 1999: 101). Understandably, Senghaas argues that, "...that holistic statements [about a civilization] have never been analytically useful" (1998: 130). So, how come Huntington makes comparisons of power among civilizations to produce an argument about the power increase or the power decline of civilizations? Let's put it in another way. It does not make sense at 
all to argue that the power of Cinic civilization is "the aggregation" of the economic, military, population and territories of China, Taiwan, North Korea, and South Korea. It also does not make sense to say that the power of Islamic civilization is "the aggregation" of the military capabilities, population, economic growth and territories of, for instance, Iran, Iraq, Saudi Arabia and Pakistan. Realists can compare the power of states because states are clear entity and unity, but not the power of "civilizations" because they have no clear-cut entity and unity. Accordingly, his argument about "the shift of balance of power" is basically groundless.

Third, the rise of civilization-based world order. Huntington argues that society sharing cultural affinity cooperates with each other and countries group themselves around the lead or core states of their civilizations. By showing the EU experience, he argues that economic cooperation will succeed if it is based on civilization affinity (Huntington, 1996: 131). He also argues that the new world order is sustained by seven center of civilizations gravity. Every center has a concentric power structure and relies on networking among core states, member states, and individuals or group members residing in foreign country.

However, Huntington's construction of civilizationbased world order is highly problematic. Although he notes that states are still the most important actors in the world politics (Huntington, 1996: 28), his analyzes of the states behavior is mainly over determined by civilizations variable. In his word, "cultural commonalties and differences shape the interest, antagonisms, and association of states" (Huntington, 1996: 29) Consequently, he overlooks the robustness of states and, in turn, fails to explain the complexities of global politics. For example, his model cannot explain the viability of cooperation among ASEAN states since 1967. In fact, this economic grouping is multicivilizational-based: it includes Islam, Buddhist, Confucian, and Christian civilizations (Muzaffar, 1994: 12). His model also fails to understand the need of Asia Pacific community to create of APEC, a multicivilizational economic cooperation. Also, the paradigm faces other anomalies: why conflicts occur within Islamic civilization, for instance, war between Iran (Islamic)-Iraq (Islamic) in 1980-1988, and Iraqi (Islamic) invasion of Kuwait (Islamic) in 1990. What kind of cooperation is it: the oil-rich (Islamic) states in the Gulf purchase weaponry from the United States (the West)? Because of the over-determined by civilizations variable, Huntington's model of civilizationalbased world politic faces too many anomalies and fails to explain the complexities of those phenomena. ${ }^{9}$ As a matter of fact, the "jigsaw puzzle" can easily be understood from the politic, economic, and security interest of states rather civilizations. State sovereignty is still one of the major realities of international relations, and the decision makers of states tend to function in manner which obtains and protects the national interest of the states. States control the civilization, not vice versa. In short, the serious weakness of Huntington's model is that, borrowing Ajami's words, it "misses the slyness of states" (Ajami, 1993: 2).

Fourth, "the West" dominance and the challenge from "the rest." Huntington warns about danger and threat that the "the west" dominance is currently challenged by the rise of "disgruntled civilizations": Confucian and Islamic civilization and the emergence of "Confucian-Islamic" alliance (Huntington, 1996: 238-240). But the arguments are very misleading. First, as has been mentioned above, Confucian civilization is not monolithic. If we look at the conflict between China and Taiwan, his observation of the Confucian unity is absolutely wrong. As Liu Binyan shows the political and ideological differences among them preventing the formations of greater "Confucian world" (Binyan, 1993). The conflict between North and South Korea is another clear example. Secondly, the worry about Islamic challenge is also a myth. The Islamic "civilization" is better characterized by "fragmentation (Chubin, Murden in Baylis, 1998). It is not an exaggeration to say that history of Middle East ("Islamic world") politics since the formation of nation-states in the region is history of tension and conflicts among "Islamic states" themselves. Mahbubani rightly points out, "it is ironic that the West should increasingly fear Islam when daily the Muslim are reminded of their 
own weakness" (Mahbubani, 1993: 12). In his book, Islam and the Myth of Confrontation, Fred Halliday persuasively challenges the myth of Islamic threat "...an Islamic threat is itself chimera, and to talk of some enduring, transhistorical conflict between the "Islamic" and "western is nonsense." On the Islamic side, it is absurd to see Muslim countries as in some general sense menacing the west. ...Today the combined strength of the Islamic world is far less than that of the west, even assuming the (almost impossible) case of the different countries forming an alliance to act unison. In reality Islamic countries have pursued individual, nation states, and often as fought each other... (Halliday, 1996: 113).

Unfortunately, Huntington swallows uncritically Bernard Lewis' article, "the Roots of Muslim rage," an essay, which distorts the current Islamic resurgence and depicts it as an irrational threat to the western heritage (Lewis, 1993).

Thirdly, the existence of Confucian-Islamic alliance (Huntington, 1996: 238-241) is also seriously misleading. The traffic of arm from China to Libya, Iran, Syria does not represent Sinic-Islamic alliance, but merely normal business venture (Ajami, 1993: 6). Also, the cooperation of nuclear weapon between China and Pakistan is not directed toward the west because of "civilizational reasons" but because of geopolitical reasons (it is directed to "balance" India's nuclear capabilities) (Ball and Malik, 1998). Similarly, it does not make sense to argues that military cooperation between rich-oil (Islamic) countries in the Gulf and the USA (west) is directed toward Confucian Civilization. In fact, it is directed toward "radical" states (Iraq, possibly Iran) in the region. In short, his argument about the threat from the "Confucian and Islamic civilization" is unconvincing and is based on groundless prejudice.

Finally, survival of the West. As a consequence of his logic and arguments, Huntington warns that to save the west, the US must reaffirm its western identity and must accept its civilization as unique, not universal. Huntington seem skeptic because he argues that the western values is unique so there is no need to impose the "western unique values" to other civilizations to avoid the clash with the rest.

However, Huntington underestimates the fact that western values are also met with approval in other, non-western society. Not primarily because they originated in the west, but because they are oriented toward the protection of individuals and their integrity. In all non-western societies there have been and there will be political and humanistic movements oriented to values, which, by change or not, have their roots in western civilization (Senghaas, 1998: 130).

\section{THE DUBIOUS ASSUMPTIONS}

What are the main assumptions behind the Clash? First, it seems that logic behind Huntington's ideas is conflict paradigm of social theory. The logic perceives that conflict is regarded as normal concomitant of group existence. Conflict paradigm perceives conflict is not only integrated, but it helps to established group identity, clarifies group boundary and contributes to group cohesion. Huntington assumes that conflict is serving "positive" social purpose. No wonder, the main discourse in the Clash is about danger, threat, and conflict! Borrowing Michael Dibdin words, he naively believes that "...there can be no true friends without true enemies. Unless we hate what we are not, we can not love what we are..." (Huntington, 1996: 20). In his map of civilizationbased world politics, he argues, for people seeking identity and reinventing ethnicity, enemies are essential...[italic from the writer]" (p.20).

Unsurprisingly, in the clash, he constructs new enemies for the west after its "old enemy" collapsed. O'Haggan aptly criticizes Huntington in her smart article, "Looking a Cultural Enemy?” (O’Hagan, 1994). In fact, constructing "us" and "them" or "friend" and "enemy" are dangerous discourses to be used to analyze the world politics and policy guidance (Devetak in Burchill, 1996: 168). As Fred Halliday also indicates, the idea that the "west need enemy" is really a myth. Yes, certain benefits arise from international and ideological/religious confrontations: arm manufactur- 
ers. That external challenges have a function to play within a society was possibly true in the case of cold war. But this does not means that the cold war arose as a result of pressure for such internal benefits.

Western society as a whole has never "needed" an enemy in some systematic sense (Halliday, 1996: 113).

Secondly, in relation to the first point, he also uses the realist view that "the international realm is the realm of the recurrence and repetition." Conflict, struggle for power and war happened in the past and will always be repeated in the future (Waltz, 1979: 66). In the past, he argues, conflicts happened among princess. After the emergence of modern nation states (the Peace of Westphalia), conflicts occurred among nation states. In the second half of the twentieth centuries, conflicts occurred among ideologies (Huntington, 1993: 23). Following the logic, he is sure that after the end of cold war there "must be" another new form of conflicts. But what? He thinks without a deep contemplation and argues that "it will happen among civilizations!”

As a matter of fact, that kind of logics is a dangerous way of thinking. Although there is a "fact" that the world politics was conflictual in the past, it does not necessary mean that it will always conflictual in the future. It is because there is no such "social fact." The social "fact" (e.g, "anarchy of global politics" and "a conflictual world," etc) is socially constructed. How we think will shape how we practice. Precisely, if we think that the international realm is conflictual it will materialize in the real world because we will behave to follow the discourse (Wendt, 1992). The Clash of Civilization is what Huntington make of it! The Clash exploits the differences among civilizations that lead to the understanding that conflicts seems inevitable. This is an intellectual setback because it constructs and reifies "the social fact" of conflictual relationships among civilizations in the global politics.

Fortunately, some Western and Moslem scholars have rejected his ugly image. Roman Herzog, for instance, argues the need to emphasize the commonalties among civilization and to avoid the possibility of conflictual relationships through the mutual under- standings and dialogue (Herzog, 1999). In the Transformation of Political Community, Andrew Linklater (1998), the proponents of critical theory in International relations, also strongly argues for new forms of political community which are cosmopolitan, sensitive to cultural difference, the importance of inclusiveness, dialogue and consent rather than the balance of power, conflict and clash.

\section{CONCLUSION}

AFTER THE SEPTEMBER 11

Huntington thesis is of little use. But, terrorist horrendous attacks at the WTC and the Pentagon (September 11) make some of us to think, "possibly, Huntington is right". "It is a clash between Islam and the West!." This is how Osama bin Laden sees things: "this battle is not between al-Qaeda and the US", the Al-Qaeda leader said in October 2001. "This is a battle of Muslims against the global crusaders". From bin Laden perspective, it is a clash that has been underway for centuries, with the American as the latest incarnation of the Christian Crusaders-arrogant Western interloper out to oppress Muslims (Christian Science Monitor, 2003).

In October 2001 interview on al-Jazeera Bin Laden talked about the Clash of Civilization thesis: Muslim, bin Laden argues, must reverse a series of humiliations that they have endured since the Ottoman Empire, the last Muslim great power, as dismantled after the World War I. Al-Qaeda's 1998 declaration of Jihad, or holy war" against "Jews and Crusaders" urge Muslim to attack "the American and their allies, civilian and the military". Supposedly as a response to US policies that al-Qaida feel oppress Muslim: the stationing of troop in Saudi Arabia, the backing of the UN sanction against Iraq, support for repressive Arab regimes, support for Israel,... These Western policies, according to al-Qaeda, added up to a clear declaration of war on Allah, his messenger, and Muslims" (Christian Science Monitor, 2003). Some, not all, Muslim in the world then see Osama is the hero.

On the other hand, some people in the West have also used the Clash of Civilizations' thesis as justification 
something that I did not write in the book [so, please read my book again!]" (Millenium, 26,1, 1997).

for going toe-to-toe with Islam in retaliation for the WTC attacks. Richard Lowry wrote in the National Review that the West should fight back in defense of its values, so did Michael Ryan in the Boston Globe. Many other American commentators have been braying for Muslim blood. In the West, because the terrorists who attacked the United States in 2001 were all Muslims, their violent action become linked to Islam

But the fact is that the vast majority of the world's more than one billion Muslim are peaceful people. Possibly, many Muslims in the world disagree with many US' policy in the Middle East. But it does not mean that they support Osama bin Laden of using violence against the West. It is a tiny number of extremists who cause the trouble. Osama bin Laden and his Al-qaeda fanatics have twisted Islam's teaching to serve their own ends (Esposito, 2002) Bin Laden is no more representative of Islam than Oklahoma City bomber Timothy McVeigh is of Christianity. The problem is that the volume of media coverage in the West often uses the word "terrorist" and "Islam" in the same sentence so that it looks as though Western society is in conflict with Islam. As has been shown, the clash of civilizations is a myth. Are we trapped in the Huntington's thesis?

\section{END NOTES}

The triumph of liberal-democratic form of governance over all rival forms of governance because of the "defeat" of other alternative ideology —absolutism, fascism, nazism, communism." Liberal democracy was free of fundamental internal contradiction, so the triumph marks the end of social evolution.

2 The coming of global disorder because of scarcity, crime, overpopulation, tribalism and disease destroy the social structure of the world.

3 The end of the cold war lead to the emergence of the United States as sole superpower because of its combination of economic, political, military power unrivaled by other powers.

4 Globalization refers to all those processes by which the people of the world are incorporate into single world society, global society. See, for instance, Martin Albrow, Globalization, Knowledge and Society, London: Saga, 1990.

5 Elaborating his main arguments in the first section of this essay is so essential to avoid a "useless debates." For instance, Professor Stephen Chen writes a strong critiques on Huntington Clash of Civilizations, (see, Millenium, 26,1, 1997), but Huntington cynically writes his response to the critics, "Professor Chen, you criticize
6 He believes that modernization and globalization do not lead to the emergence of "a global village" but a fragmented and, in turn, conflictual world

7 ' $n$ his book, Tibi recognizes the cultural differences and indigenizaton, but not like Huntington who exploits it, he seek for cultural dialogues to avoid conflict.

8 "Anarchy" is a term in International Relations that refers to a condition in the world politics which no central exist.

9 In Kuhnian logic, if a paradigm faces so many anomalies, it is in crisis, and will emerge other new paradigm that can offer better answer to the questions and, in turn, it will become dominant in the academic debate until it faces other anomalies.

\section{REFERENCES}

Ajami, Fouad The Summoning, Foreign Affairs, 72 (4) 1993 Bartley, Robert, the Case of Optimism, Foreign Affairs, Set/Oct, 1993 Binyan. Liu, Civilization Grafting, Foreign Affairs, Sept/Oct, 1993 Burchill, Burchill, and Andrew Linklater, Theories of International Relations, New York, St.Martin Press, 1996.

The Clash of Civilizations?" Christian Science Monitor, 2003

John Esposito, The Islamic Threat, Oxford: Oxford University Press, 1995, p. 207-8

John Esposito, Unholy Terror: Terror in the Name of Islam, 2002 Friedman, Thomas, The Lexus and the Olive Three, London: Harper Collins Publisher, 1999

Fukuyama, Francis, The End of History, National Interest. No. 6, Summer, 1989

Herzog, Roman, Preventing the Clash of Civilizations, New York: St. Martin Press, 1999

Huntington, Samuel, If not Civilizations, What? Paradigm of Post Cold war World, Foreign Affairs, November/December, 1993: p. 191 , The Clash of Civilizations and the Remaking of World Order, London: Touchstone Books, 1997

Ikkenberry, The West: precious, not unique, Foreign Affairs, 76 (2), 1997, p. 162

Kaplan, Robert, The Coming Anarchy, The Atlantic Monthly, 237(2), February, 1994

Krauthammer, Charles, The Unipolar Moment, Foreign Afffairs, Vol. 70. No. 1, 1991

Kung, Hans, Inter-Cultural Dialogue versus Confrontation, in Roman Herzog, 1999

Lewis, Bernard, New Perspective Quarterly, 10, 3, Summer, 1993

Linklater, Andrew, The Transformation of Political Community, Cambridge: Blackwell Publisher Ltd, Polity Press, 1998.

Mahbubani, Kishore, The Danger of Decadence, What the Rest can Teach the Rest, Foreign Affairs, September, 1993

Summer, 1998

, Can Asian Think? National Interest,

Mazrui, Ali, Islamic Western value, Foreign Affairs, September, 1997

Murden, Simon, Cultural Conflict in International Relations: The West and Islam, in John Baylis and Steve Smith, The Globalization of World Politics, Oxford: Oxford University Press, 1998

Muzzafar, Chandra, The Clash of Civilization or Camouflaging Domi- 
nance, Asian Studies Review, July, 1994

O'Hagan, Jacinta, Looking for Cultural Enemy? Third Word Quarterly, Vol. 16 No.1, 1994

Senghaas, Dieter, Clash of Civilizations: An Idee Fixe?, Journal of Peace Research, Vol 35, No. 1, 1998

Tibi, Bassam, International Morality and cross-cultural Bridging, in Roman Herzog, 1999

Waltz, Kenneth, The Theory of International Politics, Massacussett, Addison-Wesley Publishing Company, 1979:66.

Wendt, Alexander Anarchy is what state make of it, International Organization 46, 2 Spring, 1992 